\title{
Gc-Ms Analysis and Antibacterial Activity of Mangosteen Leaf Extracts against Plant Pathogenic Bacteria
}

\author{
Qamar Mohammed Naji Alsultan, Kamaruzaman Sijam*, Tavga Sulaiman Rashid, \\ Khairulmazmi Bin Ahmad \\ Department of Plant Protection, Faculty of Agriculture, University Putra Malaysia, UPM, Serdang, \\ Malaysia \\ Email: *kama@upm.edu.my
}

Received 4 April 2016; accepted 7 May 2016; published 10 May 2016

Copyright (C) 2016 by authors and Scientific Research Publishing Inc. This work is licensed under the Creative Commons Attribution International License (CC BY). http://creativecommons.org/licenses/by/4.0/ cC) (i) Open Access

\section{Abstract}

The potential of Garcinia mangostana as a biological control agent against plant pathogenic bacteria which decrease the quality and volume of crop production worldwide was assessed. Mangosteen leaves were extracted by maceration using chloroform, $n$-hexane, and methanol. For the in vitro antibacterial activity, two dissimilar species of plant pathogenic bacteria: Pseudomonas syringe pv. tomato and Xanthomonas oryzae pv. oryzae were acquired. Four different concentrations, $12.5,25,50$, and $100 \mathrm{mg} / \mathrm{ml}$ were obtained through the cup-plate agar diffusion technique. Streptomycin sulphate at $30 \mu \mathrm{g} / \mathrm{ml}$ concentration was set as the positive control, whereas every respective solvent used in the leaf extraction was set as the negative control. The results have shown that, only methanol extract demonstrated antibacterial activity when tested on the plant pathogenic bacteria. The highest diameter of inhibition zones was observed in $X$. oryzae pv. oryzae, at all range of concentrations, followed by $P$. syringae pv. tomato. The least methanol extract concentration utilised in determination of minimum inhibitory concentration (MIC) assay was at 1.562 $\mathrm{mg} / \mathrm{ml}$, inhibiting $X$. oryzae pv. oryzae, followed by $P$. syringe pv. tomato at a concentration 3.125 $\mathrm{mg} / \mathrm{ml}$. Antibacterial impacts of the most effectual extract of mangosteen crude were supported by the existence of chemical components identified by GC-MS. Cycloartenol, Caryophyllene, Docosane, Phenol, 4,4-Methylenebis (2,6-di-tert-butylphenol) and Chromium were noted as key compounds in the mangosteen leaf extract, which were perhaps causing the antibacterial activity.

\section{Keywords}

Pseudomonas syringae, Xanthomonas oryzae, Garcinia mangostana and Methanol Extract

\footnotetext{
${ }^{*}$ Corresponding author.
}

How to cite this paper: Alsultan, Q.M.N., Sijam, K., Rashid, T.S. and Ahmad, K.B. (2016) Gc-Ms Analysis and Antibacterial Activity of Mangosteen Leaf Extracts against Plant Pathogenic Bacteria. American Journal of Plant Sciences, 7, $1013-1020$. 


\section{Introduction}

Plants have served as a major source of medical compounds for several decades and many natural products have been extracted from the plants which have helped in the treatment of diseases either in the form of crude extracts or as purified compounds [1]. The medicinal plants are a best source for novel drugs and these plants provide drugs for treating a variety of conditions [2]-[4]. Several literature reports and botanical records compare the plants to the sleeping giants, which when explored, they would prove to be a massive source of beneficial properties that can improve the life and also protect humans and plants alike from several diseases [5] [6].

Several scientific studies have suggested that the mangosteen plant possesses antibacterial, antiviral, anti- fungal, anti-inflammatory, antioxidant, anti-allergic and anti-malarial properties [7]. Many scientists have carried out in vivo and in vitro studies using the G. mangostana extracts and have described that the plant extract possesses miscellaneous pharmacological activities like including neuroprotective, anti-inflammatory, anti-al- lergic, antitumoral, antioxidant, immunomodulatory, cytotoxic, antibacterial and the antiviral properties [8] [9]. Though, several reports state that the mangosteen extracts exhibit antimicrobial activities, and the plant extract is not tested against the pathogenic plant bacteria. This study aims to determine the in vitro antibacterial activities using the mangosteen leaf extract and classification of phytochemical compounds with the GC-MS procedure.

\section{Materials and Methods}

\subsection{Preparation of Mangosteen Leaf Extracts}

The fresh Mangosteen leaves have been obtained from a Mangosteen Farm, situated in the University Agricultural Park, University Putra, Malaysia. Then, these leaves were washed and further rinsed with the distilled water till the excess dirt and the insects sticking to the leaf surface were washed off. The leaves were placed on a table top to remove the excessive moisture and left to dry at the room temperature for 10 days. The dried leaves were ground to a powder with the help of a cross beater mill (SK100, Retsch) machine and sieved through a sieve having a pore size of $0.50 \mathrm{~mm}$ (SK100, Retsch).

Solvents, with differing polarities (methanol, hexane and chloroform), were used for extraction. Initially, for determining the best solvent, extraction was carried out using small quantities $(20 \mathrm{~g} / 200 \mathrm{ml}$ solvent $)$. The solvent-powder mixture was soaked in $250 \mathrm{ml}$ conical flasks and sealed with an aluminium foil and kept on a rotary shaker at $30^{\circ} \mathrm{C}$ for $48 \mathrm{~h}$. This slurry was then passed through a Whatman No. 1 filter paper $\left(\mathrm{ALBERT}^{\mathrm{R}}\right)$, at the end of $48 \mathrm{~h}$. The solvent was evaporated with the help of a rotary evaporator (Hahn Shin Scientific Co., Tai-

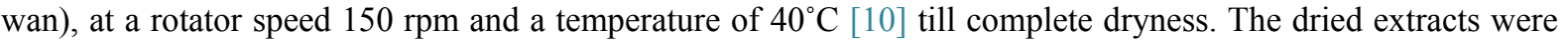
placed in the chiller at $4^{\circ} \mathrm{C}$ till further use.

\subsection{Preparation of Bacterial Culture}

Xanthomonasoryzae pv. oryzae (Accession number CP000967.1) and Pseudomonas syringe pv. tomato (Accession number KR261604) the causal agents of bacteria rice diseases and tomato bacterial speck respectively were obtained from the culture collection of Plant pathology Laboratories, Faculty of Agriculture, University Putra Malaysia.

A loopful of the $24 \mathrm{~h}$ old bacterial culture, cultivated on agar plates, was transferred to $30 \mathrm{ml}$ test tubes which contained sterile distilled water and was mixed by vortexing. The bacterial density was adjusted to reach a value of Optical Density $(\mathrm{OD})=0.1$ measured at $660 \mathrm{~nm}$ wavelength [11].

\subsection{In Vitro Evaluation of Antibacterial Activity}

Efficacy of the mangosteen leaf extracts was determined in vitro by the agar well diffusion assays, as described previously [12] with slight modifications. The assay was conducted using $9 \mathrm{~cm}$ petri plates that contained $20 \mathrm{ml}$ of the Muller-Hinton Agar (MHA) culture medium. $50 \mu \mathrm{l}$ of the bacterial cell suspension was pipetted out onto the agar plates and then spread on the solid media using an L-shaped glass rod, for ensuring a homogeneous spread of the culture. The whole spread plate experiment was carried out in the laminar flow to prevent any kind of contamination. Once the plates has dried out, 6 wells were bored in the plated using a sterile cork borer $(0.4$ $\mathrm{mm}) .50 \mu \mathrm{l}$ of the different plant extracts were added to every well. The concentration of the extracts was 12.5 , 25,50 and $100 \mathrm{mg} / \mathrm{ml}$. 2 wells were filled with $50 \mu \mathrm{l}$ of the streptomycin sulphate $(30 \mu \mathrm{g} / \mathrm{ml})$ solution, which 
represented as a positive control. The plates were left to dry for $3 \mathrm{~h}$. Then, the plates were inverted and were incubated for $24 \mathrm{~h}$ at $30^{\circ} \mathrm{C}$. The same test was performed in 4 different replicates. The bacterial growth was estimated by calculating the diameters of the zone of inhibition which was seen around the wells, using a ruler graduated in millimetres $(\mathrm{mm})$.

\subsection{Determination of Minimum Inhibitory Concentration (MIC) and Minimum Bacterial Concentration (MBC)}

The MIC for the methanolic extract was studied using the broth micro dilution technique by the 2-fold serial dilution method. The MIC assay was based on the lowest concentrations of the most effective plant extracts, which inhibited the bacteria in the agar plate assay. Based on the results of the in vitro assay, the least concentration for the MIC estimation was considered to be $12.5 \mathrm{mg} / \mathrm{ml}$. Eleven capped test tubes were also filled with $1 \mathrm{ml}$ of the Mueller Hinton Broth (MHB, Oxoid) and then sterilized in an autoclave at $121^{\circ} \mathrm{C}$ for 20 mins. To the test tube 1 , a concentrated plant extract $(50 \mathrm{mg} / \mathrm{mL})$ was added to obtain a final concentration of $12.5 \mathrm{mg} / \mathrm{mL}$. Thereafter, a 2-fold dilution was carried out from the test tube $1-10$. Test tube 11 contained only the MHB without any extract. Throughout the whole experiment, the bacterial density was kept constant at $0.1 \mathrm{OD}_{660}$. $100 \mu 1$ of the microbial cell suspension was also added to all the test tubes except test tube 10 and was mixed well. The test tube 10 containing no microorganisms but only the extracts and the broth served as a positive control, whereas the test tube 11 containing a mixture of the broth and microbes was the negative control for the assay. Thereafter, $50 \mu \mathrm{l}$ of the aqueous solution of 2,3,5-TriphenlTetrazolium Chloride (TTC, stock of $2 \mathrm{mg} / \mathrm{ml}$, Sigma) was also added to all the test tubes as an indicator dye to determine the microbial growth. These tubes were then incubated for $24 \mathrm{~h}$ at $30^{\circ} \mathrm{C}$. The MIC represented the lowest concentration of the plant extract which did not show any colour change [13].

The MBC values were evaluated by sub culturing the culture from the tube that did not show any colour change, on sterilised MHA plates. The plates were incubated at $30^{\circ} \mathrm{C}$, overnight. $\mathrm{MBC}$ value was determined as the lowest concentration that did not show any visible growth on the agar plates [11].

\subsection{Gas Chromatography-Mass Spectrometry (GC-MS) Analysis}

The changeable volatile compounds profiling of methanol extract from mangosteen leaves was measured using GC-MS. The compounds in the extract were quantitatively calculated using GCMS concentrated around the method described by [14]. The dried crude extract was dissolved in $0.1 \mathrm{~g} / \mathrm{ml}$ of methanol and a measure of 1.5 $\mu 1$ was added in the GC-MS spectrophotometer. The GC-MS employed for the testing was a Shimadzu GC-17A attached to Shimadzu GC-MS-QP5050A system. The column used was Phenomenex Zebron ZBFFAP ultralow-bleed Bonded Polyethylene Glycol fused capillary column $(30 \mathrm{ml} \times 0.25 \mathrm{~mm} \mathrm{I.D} \times 0.25 \mu \mathrm{M}$ film thickness $)$. Split ratio 20 injection was carried out. Helium gas at a stream flow rate of $0.7 \mathrm{ml} / \mathrm{min}$. was used as the transporter carrier gas and the column temperature was maintained at $70^{\circ} \mathrm{C}$ for 3 minutes, followed by modified programming at $10^{\circ} \mathrm{C} / \mathrm{min}$ to $90^{\circ} \mathrm{C}$ and after that at $5^{\circ} \mathrm{C} / \mathrm{min}$ to $230^{\circ} \mathrm{C}$. The inlet and detector temperature was $230^{\circ} \mathrm{C}$ and $250^{\circ} \mathrm{C}$, respectively. The dissolvable deferral (solvent delay) was 5.75 minutes [15].

\subsection{Statistical Analysis}

SAS software version 9.2 was used to perform the Analysis of Variance (ANOVA) (Cary, NC: SAS Institute Inc. 2011). LSD test at the 0.05 probability level was used to determine the statistical differences among the different bacteria and fungi isolates.

\section{Results}

\subsection{In Vitro Evaluation of Antibacterial Activity}

The antibacterial activity in the case of every crude extract sample was determined by the presence or the absence of the inhibitory zone around the well. The G. mangostana chloroform and the n-hexane extracts did not depict any antibacterial activity against the pathogenic bacteria.

However, the methanolic crude extract displayed antibacterial activity against both the microorganisms that were tested (Table 1). The methanolic extracts displayed zones of inhibition ranging from a diameter of 12.6 $20.5 \mathrm{~mm}$. The positive control of streptomycin sulphate displayed the diameter of the inhibitory zone in the 
Table 1. Antibacterial activity of G. mangostana methanol leaf crude extract against pathogenic bacteria.

\begin{tabular}{ccc}
\hline Concentration $(\mathbf{m g} / \mathbf{m l})$ & Inhibition zone $(\mathbf{m m})$ & \\
& P. syringae $\mathbf{~ p v . ~ t o m a t o ~}$ & X. oryzae pv. oryzae \\
\hline Positive control & $19 \pm 0.5 \mathrm{a}$ & $18 \pm 0.3 \mathrm{ab}$ \\
Negative control & $0 \pm 0 \mathrm{e}$ & $0 \pm 0 \mathrm{e}$ \\
100 & $17.6 \pm 0.3 \mathrm{~b}$ & $20.5 \pm 0.2 \mathrm{a}$ \\
50 & $16.8 \pm 0.1 \mathrm{~b}$ & $18 \pm 0.3 \mathrm{~b}$ \\
25 & $15 \pm 0.5 \mathrm{c}$ & $16.5 \pm 0.2 \mathrm{c}$ \\
12.5 & $12.6 \pm 0.3 \mathrm{~d}$ & $13.1 \pm 0.6 \mathrm{~d}$ \\
\hline
\end{tabular}

Means with same letter in the same column are not statistically different at 0.05 level.

range of $18-19 \mathrm{~mm}$. The negative control did not display any inhibition against the pathogenic bacteria. Methanolic extract, with the lowest concentration $(12.5 \mathrm{mg} / \mathrm{ml})$ was able to inhibit the bacterial growth for the test microbes- $P$. syringae pv. tomato and $X$. oryzae pv. oryzae. For the highest extract concentration of $100 \mathrm{mg} /$ $\mathrm{ml}$, the highest zone of inhibition was displayed by $X$. oryzae $(20.5 \mathrm{~mm})$ which was higher than positive control and then by $P$. syringae $(17.6 \mathrm{~mm})$. The assay indicated that as the concentration of the crude extract increased, the antibacterial activity also increased with significantly differences (Figure 1).

\subsection{The MIC and MBC}

The methanol extract was able to inhibit the growth of the bacterial species that were tested. Out of the two species, $X$. oryzae was seen to be more vulnerable to the methanolic extract. The least concentration of the methanolic extract that could inhibit the pathogenic bacteria species, was $1.562 \mathrm{mg} / \mathrm{ml}$. in the case of the MBC, the least concentration that exhibited the bactericidal effect was $3.125 \mathrm{mg} / \mathrm{ml}$ for $X$. oryzae, which was followed then by $P$. syringae.

\subsection{Analysis of the Phytocompounds from Methanol Crude Extract Using Gas Chromatography-Mass Spectrometry (GC-MS)}

The outcome of the GC-MS dissection indicates the identifiable evidence of several compounds from GC divisions of the methanol extract of the G. mangostana. The compounds were differentiated with the help of mass spectrometry linked to GC. The most important highest placated components revealed in the considered crude extract found with the help of GC-MS are illustrated in Table 2. The GC-MS spectrum range confirmed the vicinity of 314 varied constituents with different retention times (Figure 2) beside twelve elements in the high peak section (Caryophyllene, Spinacene, 2-(2-Quinolinyl)-1-naphthol, 2-(2-Quinolinyl)-1-naphthol, Silane, dimethyl (1-phenylpropoxy) tridecyloxy-, 12.beta.-Hydroxy-5.alpha.-pregnane, methoxyacetate, Phenol, 4,4'-(1methylethylidene) bis-, Chromium, cyclopentadienyl-hexaethylbenzene, Docosane, 3,5-Dimethyldocosane, Cycloartenol, 4,4'-Methylenebis (2,6-di-tert-butylphenol), and Terephthalylidenebis (p-butylaniline)). With regards to the percentage amount, Caryophyllene (3.87\%), docosane (5.50\%), Cycloartenol (4.16\%) and Phenol, 4,4'-Methylenebis (2,6-di-tert-butylphenol) (3.97\%) were noticeable in G. mangostana which may possibly add to the antimicrobial feature of the plant.

\section{Discussion}

Out of the three solvents, the polar solvent, methanol was seen to be the best solvent for extraction, which has already been reported by several other studies [16] [17]. There are many studies which state, that methanol is more effective for the extraction of low molecular weight polyphenolic compounds [18].

The GML leaf methanolic crude extract exhibited broad spectrum antibacterial activities and displayed bacteriostatic effects against the tested pathogenic bacteria. Several other studies have also reported that methanolic leaf extracts were able to inhibit the pathogenic bacteria species at very low concentrations [19] [20]. The GML plant has displayed an antibacterial effect against the pathogenic bacteria like Staphylococcus albus, Staphylococcus aureus, and Micrococcus lutus [21] [22]. 


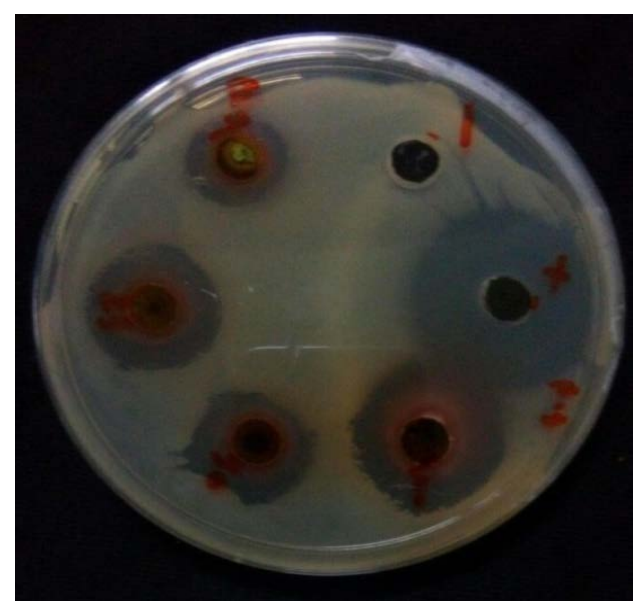

(a)

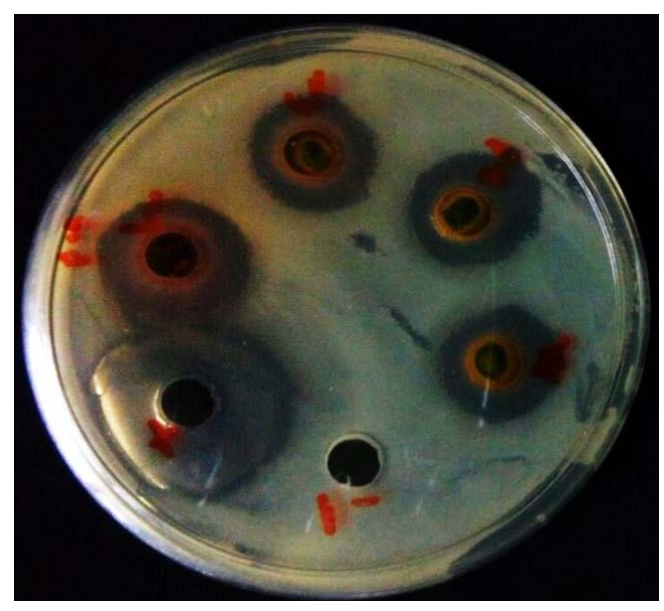

(b)

Figure 1. Antibacterial activity of $G$. mangostana methanol leaf crude extract against $P$. syringae (a) and X. oryzae (b).

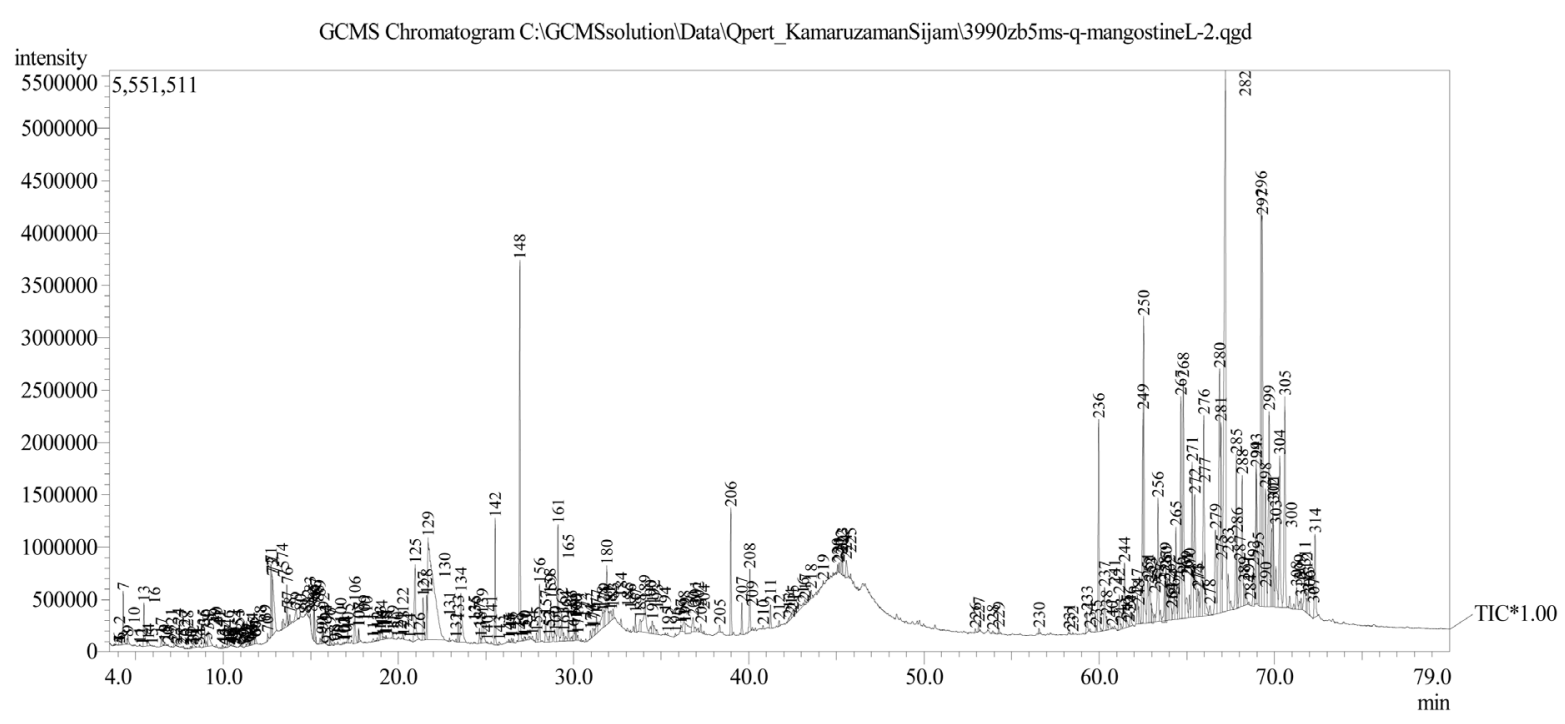

Figure 2. GC-MS chromatogram analysis of methanol leaf extract of mangosteen.

One study has stated that the mangosteen leaf extract was very effective against both, the Gram positive and the Gram negative bacteria, specifically those that were linked with skin infections like acne, diarrhoea, tuberculosis etc. [23] [24]. It was also seen that the methanolic extracts of mangosteen leaves inhibited the growth of the pathogen, $S$. aureus and also displayed activity against the Methicillin-Resistant S. aureus strains (MRSA) [25].

The chemical components in the leaf extract of G. mangostana lead to inhibition and antibacterial actions compared to $P$. syringae and $X$. oryzae. Based on the GC-MS, the outcome of the research established the existence of 314 different phytocompounds. Latest research has demonstrated that many of these compounds may result in the direct inhibition of the fungal and bacterial pathogens. For example, caryophyllene has been generally employed as a fragrance chemical from the 1930s and is used in spice mixes, soaps, citrus flavours, detergents, lotions, and creams, as well as in a number of food products and drinks. Caryophyllene is widely recognised for its anti-inflammatory and local anaesthetic features [26]. As caryophyllene and germacrene-D, which are the ingredients of essential oils, can be refined [27], the studied plants become latent substitutional sources of these vital bioactive compounds.

Montanari et al. [28] detected caryophyllene from the leaves of Verbenaceae species Aloysiavirgata, Lantanacamara, L. trifolia, L. montevidensis, Lippia brasiliensis, and L. sericea and identified the antibacterial 
Table 2. The major highest placated components exhibited in the methanol crude extract of mangosteen identified based on GC-MS analysis.

\begin{tabular}{|c|c|c|c|c|}
\hline Peak No. & Component name & Formula & $\begin{array}{l}\text { Retention } \\
\text { Time }\end{array}$ & $\%$ Total extract \\
\hline 129 & 1,2 benzenediol & $\mathrm{C}_{6} \mathrm{H}_{6} \mathrm{O}_{2}$ & 21.689 & 1.04 \\
\hline 142 & Copaene & $\mathrm{C}_{15} \mathrm{H}_{24}$ & 25.534 & 1.29 \\
\hline 148 & Caryophllene & $\mathrm{C}_{15} \mathrm{H}_{24}$ & 26.931 & 3.87 \\
\hline 161 & Naphthalene & $\mathrm{C}_{15} \mathrm{H}_{24}$ & 1.29 & 1.29 \\
\hline 206 & Oley alcohol & $\mathrm{C}_{20} \mathrm{H}_{40} \mathrm{O}$ & 38.975 & 1.30 \\
\hline 236 & Spinacene & $\mathrm{C}_{30} \mathrm{H}_{50}$ & 59.967 & 2.16 \\
\hline 249 & 2-Buty1(dimethy1) silyoxytridecane & $\mathrm{C}_{19} \mathrm{H}_{42} \mathrm{OSI}$ & 62.500 & 2.16 \\
\hline 250 & 2-(2-Quinolinyl)-1-naphthol & $\mathrm{C}_{19} \mathrm{H}_{13} \mathrm{NO}$ & 62.538 & 2.12 \\
\hline 256 & (22E)-Stigmasta-5,22-dien-3-yl acetate & $\mathrm{C}_{31} \mathrm{H}_{50} \mathrm{O}_{2}$ & 63.355 & 1.26 \\
\hline 267 & Silane,dimethyl(1-phenylpropoxy)tridecyloxy & $\mathrm{C}_{24} \mathrm{H}_{44} \mathrm{O}_{2} \mathrm{Si}$ & 64.665 & 2.26 \\
\hline 268 & 12.beta.-Hydroxy-5.alpha.-pregnane, methoxyacetate (ester) & $\mathrm{C}_{24} \mathrm{H}_{40} \mathrm{O}_{3}$ & 64.798 & 2.44 \\
\hline 271 & dl-.alpha.-Tocopherol, Vitamin E & $\mathrm{C}_{29} \mathrm{H}_{50} \mathrm{O}_{2}$ & 65.304 & 1.58 \\
\hline 272 & 5,6-Dibromovanillin & $\mathrm{C}_{24} \mathrm{H}_{50}$ & 65.449 & 1.25 \\
\hline 276 & Phenol,4,4'-(1-methylethylidene)bis [2,6-dimethyl] & $\mathrm{C}_{19} \mathrm{H}_{24} \mathrm{O}_{2}$ & 65.969 & 2.04 \\
\hline 280 & Chromium & $\mathrm{C}_{23} \mathrm{H}_{35} \mathrm{Cr}$ & 66.869 & 2.49 \\
\hline 281 & 7-(4-Methyl-5-phenyl-2H-1,2,3-triazol-2-yl)-3-phenyl-2H-ch & $\mathrm{C}_{24} \mathrm{H}_{17} \mathrm{~N}_{3} \mathrm{O}_{2}$ & 66.950 & 1.93 \\
\hline 282 & Docosane & $\mathrm{C}_{24} \mathrm{H}_{50}$ & 66.950 & 5.50 \\
\hline 285 & Mesitol,.alpha.4-(3,5-di-tert-butyl-4-hydroxyphenyl) & $\mathrm{C}_{23} \mathrm{H}_{32} \mathrm{O}_{2}$ & 67.826 & 1.57 \\
\hline 288 & [1]Benzothiopyrano[4,3-b]benzo[e]indole & $\mathrm{C}_{19} \mathrm{H}_{11} \mathrm{NS}$ & 68.161 & 1.33 \\
\hline 293 & 2-(4-Iodo-phenyl)-5-propyl-pyrazolo[1,5-a]pyrimidin-7-ol & $\mathrm{C}_{15} \mathrm{H}_{14} \mathrm{INO}_{30}$ & 68.967 & 1.47 \\
\hline 296 & Cycloartenol & $\mathrm{C}_{30} \mathrm{H}_{50} \mathrm{O}$ & 69.244 & 4.16 \\
\hline 297 & Phenol,4,4'-methylenebis[2-(1,1-dimethylethyl)-6-methyl] & $\mathrm{C}_{23} \mathrm{H}_{32} \mathrm{O}_{2}$ & 69.304 & 3.97 \\
\hline 298 & 5-(3-[2-(4-tert-Butylphenoxy)ethoxy]benzylidene) & $\mathrm{C}_{23} \mathrm{H}_{24} \mathrm{~N}_{2} \mathrm{O}_{5}$ & 96.483 & 1.20 \\
\hline 299 & $2,2,4,4,6,6,8,8$-Octaethyl-[1,3,5,7,2,4,6,8] tetroxatetasilocane & $\mathrm{C}_{16} \mathrm{H}_{40} \mathrm{O}_{4} \mathrm{Si}_{4}$ & 69.896 & 1.99 \\
\hline 301 & Tri-O-methylparvisoflavone-A & $\mathrm{C}_{23} \mathrm{H}_{22} \mathrm{O}_{6}$ & 69.925 & 1.08 \\
\hline 302 & Mesitol, .alpha.4-(3,5-di-tert-butyl-4-hydroxyphenyl) & $\mathrm{C}_{23} \mathrm{H}_{32} \mathrm{O}_{2}$ & 69.933 & 1.05 \\
\hline 304 & 3,5-Bis[4-(4,5-dihydro-1H-imidazol-2-yl)]pyridine & $\mathrm{C}_{23} \mathrm{H}_{21} \mathrm{~N}_{5}$ & 70.305 & 1.54 \\
\hline 305 & Terephthalylidenebis(p-butylaniline) & $\mathrm{C}_{28} \mathrm{H}_{32} \mathrm{~N}_{2}$ & 70.598 & 2.14 \\
\hline
\end{tabular}

activity of caryophyllene compared to Staphylococcus aureus, Bacillus cereus, and Escherichia coli. Another research by Kim et al. [29] carried out on the bactericidal action of caryophyllene was observed for five Grampositive and four Gram-negative foodborne bacteria; it was greatly improved compared to Streptococcus aureus and Vibrio parahaemolyticus. Radulovic et al. [30] detected dodecane and 170 other compounds from Geranium columbinumand G. lucidum with the help of GC-MS and noted their antimicrobial actions in contrast to C. albicans.

Momo et al. [31] detected Cycloartenol from the stem bark of Garcinialucida Vesque and noted antibacterial activity in contrast to Escherichia coli, Pseudomonas aeruginosa, Salmonella typhi, Staphylococcus aureus, and Candida albicans.

Lastly, a large number of the constituents were detected from the methanol leaf extract of G. mangostana with the help of GC-MS, in accord with [32] [33]. 


\section{Conclusion}

The Mangosteen leaf methanolic extract displayed antibacterial activity against the plant pathogens like $X$. oryzae and $P$. syringae. This leaf extract could also exhibit bacteriostatic and bactericidal effect against these pathogenic bacteria. The leaf extract was seen to be bacteriostatic at the lower crude extract concentrations, while it was bactericidal at the higher concentrations, thus exhibiting the MIC and the MBC values. Likewise, as per the detection of chemical components in GCMS, it comprises (Caryophyllene, docosane, Cycloartenol, and 4,4-Methylenebis (2,6-di-tert-butylphenol)) that have been proposed to play a main part in the antimicrobial actions. It is determined that, in this current investigation, the mangosteen leaves comprise possibly antibacterial constituents that are beneficial for the growth of natural bactericide.

\section{References}

[1] Cragg, G.M. and Newman, D.J. (2013) Natural Products: A Continuing Source of Novel Drug Leads. Biochimica et Biophysica Acta $(B B A)$ —General Subjects, 1830, 3670-3695. http://dx.doi.org/10.1016/j.bbagen.2013.02.008

[2] Ji, H.F., Li, X.J. and Zhang, H.Y. (2009) Natural Products and Drug Discovery. EMBO Reports, 10, 194-200. http://dx.doi.org/10.1038/embor.2009.12

[3] Tomlinson, T.R. and Akerele, O. (2015) Medicinal Plants: Their Role in Health and Biodiversity. University of Pennsylvania Press, Philadelphia.

[4] Baharvand-Ahmadi, B., Bahmani, M., Eftekhari, Z., Jelodari, M. and Mirhoseini, M. (2016) Overview of Medicinal Plants Used for Cardiovascular System Disorders and Diseases in Ethnobotany of Different Areas in Iran. Journal of Herb Med Pharmacology, 5, 39-44.

[5] Blumenthal, M. (2009) African Natural Plant Products: A Foreword to the Science and Challenges. In: Juliani, H.R., Simon, J.E. and Ho, C.T., Eds., African Natural Plant Products: New Discoveries and Challenges in Chemistry and Quality (American Chemical Society Symposium Series), Oxford University Press, Oxford, 3-5.

[6] Bernhoft, A., Siem, H., Bjertness, E., Meltzer, M., Flaten, T., Holmsen, E. and Aaseth, J.O. (2010) Bioactive Compounds in Plants-Benefits and Risks for Man and Animals. Proceedings from a Symposium Held at the Norwegian Academy of Science and Letters, Novus Forlag, Oslo, $255 \mathrm{p}$.

[7] Xie, Z., Sintara, M., Chang, T. and Ou, B. (2015) Daily Consumption of a Mangosteen-Based Drink Improves in Vivo Antioxidant and Anti-Inflammatory Biomarkers in Healthy Adults: A Randomized, Double-Blind, Placebo-Controlled Clinical Trial. Food Science \& Nutrition, 3, 342-348. http://dx.doi.org/10.1002/fsn3.225

[8] Shan, T., Ma, Q., Guo, K., Liu, J., Li, W., Wang, F. and Wu, E. (2011) Xanthones from Mangosteen Extracts as Natural Chemopreventive Agents: Potential Anticancer Drugs. Current Molecular Medicine, 11, 666. http://dx.doi.org/10.2174/156652411797536679

[9] Al-Massarani, S.M., El Gamal, A.A., Al-Musayeib, N.M., Mothana, R.A., Basudan, O.A., Al-Rehaily, A.J. and Maes, L. (2013) Phytochemical, Antimicrobial and Antiprotozoal Evaluation of Garciniamangostana Pericarp and $\alpha$-Mangostin, Its Major Xanthone Derivative. Molecules, 18, 10599-10608. http://dx.doi.org/10.3390/molecules180910599

[10] Singh, S., Srivastava, R. and Choudhary, S. (2010) Antifungal and HPLC Analysis of the Crude Extracts of Acorus calamus, Tinospora cordifolia and Celestrus paniculatus. Journal of Agricultural Technology, 6, 149-158.

[11] Taweechaisupapong, S., Singhara, S., Lertsatitthanakorn, P. and Khunkitti, W. (2010) Antimicrobial Effects of Boesenbergia pandurata and Piper sarmentosum Leaf Extracts on Planktonic Cells and Biofilm of Oral Pathogens. Pakistan Journal of Pharmaceutical Sciences, 23, 224-231.

[12] Patel, R.J., Patel, A., Vaghasiya, D. and Nagee, A. (2012) Antimicrobial Evaluation of Hibiscus Rosa sinensis Plant Extracts against Some Pathogenic Bacteria. Bulletin of Environmental and Scientific Research, 1, 14-17.

[13] Khaleel, A.I., Sijam, K., Rashid, T.S. and Ahmad, K.B. (2016) Phytochemical Determination and Antibacterial Activity of Punicagranatum Peel Extracts against Plant Pathogenic Bacteria. American Journal of Plant Sciences, 7, 159. http://dx.doi.org/10.4236/ajps.2016.71017

[14] Hossain, M. and Rahman, A. (2011) Chemical Composition of Bioactive Compounds by GC-MS Screening and Anti-Fungal Properties of the Crude Extracts of Cabbage Samples. Asian Journal of Biotechnology, 3, 68-76. http://dx.doi.org/10.3923/ajbkr.2011.68.76

[15] Rashid, T.S., Sijam, K., Kadir, J., Saud, H.M., Awla, H.K., Zulperi, D. and Hata, E.M. (2016) Screening for Active Compounds in Rhuscoriaria L. Crude Extract That Inhibit the Growth of Pseudomonas syringae and Ralstonia solanacearum. Indian Journal of Agricultural Research, 50, 15-21. http://dx.doi.org/10.18805/ijare.v50i1.8583

[16] Razali, N., Mat-Junit, S., Abdul-Muthalib, A.F., Subramaniam, S. and Abdul-Aziz, A. (2012) Effects of Various Sol- 
vents on the Extraction of Antioxidant Phenolics from the Leaves, Seeds, Veins and Skins of Tamarindus indica L. Food Chemistry, 131, 441-448. http://dx.doi.org/10.1016/j.foodchem.2011.09.001

[17] Butsat, S. and Siriamornpun, S. (2016) Effect of Solvent Types and Extraction Times on Phenolic and Flavonoid Contents and Antioxidant Activity in Leaf Extracts of Amomum chinense C. International Food Research Journal, 23, 180187.

[18] Dai, J. and Mumper, R.J. (2010) Plant Phenolics: Extraction, Analysis and Their Antioxidant and Anticancer Properties. Molecules, 15, 7313-7352. http://dx.doi.org/10.3390/molecules 15107313

[19] Pedraza-Chaverri, J., Cárdenas-Rodríguez, N., Orozco-Ibarra, M. and Pérez-Rojas, J.M. (2008) Medicinal Properties of Mangosteen (Garcinia mangostana). Food and Chemical Toxicology, 46, 3227-3239. http://dx.doi.org/10.1016/j.fet.2008.07.024

[20] Palakawong, C., Sophanodora, P., Pisuchpen, S. and Phongpaichit, S. (2010) Antioxidant and Antimicrobial Activities of Crude Extracts from Mangosteen (Garcinia mangostana L.) Parts and some Essential Oils. International Food Research Journal, 17, 583-589.

[21] Lim, M.A.S.C., Defante, M.J.D., Yniguez, C.L.B. and Concepcion, F. (2005) Antibacterial Activity of Formulated Ointment from Crude Mangosteen (Garcinia mangostana L.) Leaf Extract against Staphylococcus aureus.

[22] Priya, V., Jainu, M., Mohan, S.K., Saraswathi, P. and Gopan, S.C. (2010) Antimicrobial Activity of Pericarp Extract of Garcinia mangostana Linn. International Journal of Pharma Sciences and Research, 1, 278-281.

[23] Suksamrarn, S., Suwannapoch, N., Phakhodee, W., Thanuhiranlert, J., Ratananukul, P., Chimnoi, N. and Suksamrarn, A. (2003) Antimycobacterial Activity of Prenylated Xanthones from the Fruits of Garcinia mangostana. Chemical and Pharmaceutical Bulletin, 51, 857-859. http://dx.doi.org/10.1248/cpb.51.857

[24] Torrungruang, K., Vichienroj, P. and Chutimaworapan, S. (2013) Antibacterial Activity of Mangosteen Pericarp Extract against Cariogenic Streptococcus mutans. Chulalongkorn University Dental Journal, 30, 1-10.

[25] Iinuma, M., Tosa, H., Tanaka, T., Asai, F., Kobayashl, Y., Shimano, R. and Miyauchi, K.I. (1996) Antibacterial Activity of Xanthones from Guttiferaeous Plants against Methicillin-Resistant Staphylococcus aureus. Journal of Pharmacy and Pharmacology, 48, 861-865. http://dx.doi.org/10.1111/j.2042-7158.1996.tb03988.x

[26] Ghelardini, C., Galeotti, N., Mannelli, L.D.C., Mazzanti, G. and Bartolini, A. (2001) Local Anaesthetic Activity of $\beta$-Caryophyllene. IlFarmaco, 56, 387-389. http://dx.doi.org/10.1016/S0014-827X(01)01092-8

[27] Brochini, C.B., Núñez, C.V., Moreira, I.C., Roque, N.F., Chaves, M.H. and Martins, D. (1999) Identificação de componentes de oleos voláteis: Análise espectroscópica de misturas de sesquiterpenos. Química Nova, 22, 37-40. http://dx.doi.org/10.1590/S0100-40421999000100008

[28] Montanari, R.M., Barbosa, L.C., Demuner, A.J., Silva, C.J., Carvalho, L.S. and Andrade, N.J. (2011) Chemical Composition and Antibacterial Activity of Essential Oils from Verbenaceae Species: Alternative Sources of $(E)$-Caryophyllene and Germacrene-D. Química Nova, 34, 1550-1555. http://dx.doi.org/10.1590/S0100-40422011000900013

[29] Kim, Y.S., Park, S.J., Lee, E.J., Cerbo, R.M., Lee, S.M., Ryu, C.H. and Ha, Y.L. (2008) Antibacterial Compounds from Rose Bengal-Sensitized Photooxidation of $\beta$-Caryophyllene. Journal of Food Science, 73, C540-C545. http://dx.doi.org/10.1111/j.1750-3841.2008.00879.x

[30] Radulovic, N., Dekic, M., Stojanovic-Radic, Z. and Palic, R. (2011) Chemical Composition and Antimicrobial Activity of the Essential Oils of Geranium columbinum L. and G. lucidum L. (Geraniaceae). Turkish Journal of Chemistry, 35, 499-512.

[31] Momo, I.J., Kuete, V., Dufat, H., Michel, S. and Wandji, J. (2011) Antimicrobial Activity of the Methanolic Extract and Compounds from the Stem Bark of Garcinia lucida Vesque (Clusiaceae). International Journal of Pharmacy and Pharmaceutical Sciences, 3, 215-217.

[32] Obolskiy, D., Pischel, I., Siriwatanametanon, N. and Heinrich, M. (2009) Garcinia mangostana L.: A Phytochemical and Pharmacological Review. Phytotherapy Research, 23, 1047-1065. http://dx.doi.org/10.1002/ptr.2730

[33] Gutierrez-Orozco, F. and Failla, M.L. (2013) Biological Activities and Bioavailability of Mangosteen Xanthones: A Critical Review of the Current Evidence. Nutrients, 5, 3163-3183. http://dx.doi.org/10.3390/nu5083163 